Бражнікова Л.М., д-р екон. наук, професор кафедри обліку і аудиту, Гарна C.O., cm. викладач кафедри обліку і аудиту, Шнурко А.M., cm. викладач кафедри обліку і аудиту, ДВНЗ «Донбаський державний педагогічний університет»

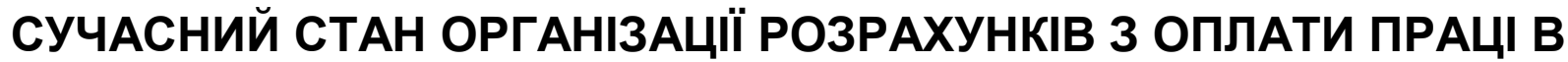 УМОВАХ РОЗВИТКУ ІНФОРМАЦІЙНИХ ТЕХНОЛОГІЙ
}

Brazhnikova L.M., dr.sc.(econ.), professor at the department of accounting and auditing, Harna S.O., senior lecturer at the department of accounting and auditing, Shnurko A.M., senior lecturer at the department of accounting and auditing, SHEI "Donbas State Pedagogical University"

\section{THE CURRENT STATE OF ORGANIZATION OF PAYROLL CALCULATIONS IN THE CONDITIONS OF DEVELOPMENT OF INFORMATION TECHNOLOGIES}

Постановка проблеми. Заробітна плата є основним джерелом доходу та впливає на якість і рівень життя працездатного населення України. Логічно, що працівник завжди бажає мати більш високий рівень оплати праці, тоді як роботодавець прагне скоротити свої витрати, в тому числі і витрати на оплату праці. Держава зі своєї сторони здійснює регулювання оплати праці працівників підприємств усіх форм власності шляхом встановлення розміру мінімальної заробітної плати та інших державних норм і гарантій, а також шляхом оподаткування доходів працівників. В сучасних умовах господарювання організація обліку оплати праці на підприємстві потребує більш детального дослідження, адже вона виконує такі важливі функції, як відтворювальну і стимулюючу. Облік оплати праці $є$ одним з найбільш важливих і трудомістких ділянок бухгалтерського обліку. Робота на такій ділянці вимагає як профресійного підходу, знання галузевих особливостей, ретельного вивчення постійних змін законодавчої бази, своєчасного здійснення розрахунків, так і відображення інформації про заробітну плату у звітності підприємства в умовах розвитку інформаційних технологій.

Отже, саме необхідність дослідження впливу рівня оплати праці на якість життя населення, а також виокремлення існуючих проблем та вироблення методики їх подолання зумовлює актуальність нашого дослідження.

Аналіз останніх досліджень і публікацій. Теоретичні та методичні аспекти сучасного стану організації розрахунків з оплати праці розглядають вітчизняні науковці, зокрема: Гапоненко Н. Л., Гордієнко Є. С., Демченко Т. М., Коблянська О.І., Кантаєва О. В., Потриваєва Н. В., Сирцева С. В. Дослідження вказаних авторів охоплюють значний спектр питань з оплати праці, розглядають найважливіші невирішені питання. Проте, постійні зміни у законодавстві, стрімкий розвиток інформаційних технологій вимагають комплексного підходу до організації обліку оплати праці та потребують додаткового наукового обговорення цього питання.

Постановка завдання. Мета статті полягає у дослідженні сучасного стану організації розрахунків з оплати праці в контексті постійної зміни нормативно-правової бази та в умовах розвитку інфрормаційних технологій. Досягнення зазначеної мети передбачає конкретизацію завдань дослідження, а саме: проаналізувати основні нормативно-правові акти, що регламентують облік розрахунків з оплати праці, а також визначити проблеми у даній сфрері та окреслити шляхи їх подолання.

Виклад основного матеріалу дослідження. Законом України «Про оплату праці» визначено, що заробітна плата - це винагорода, обчислена, як правило, у грошовому виразі, яку за трудовим 
договором власник або уповноважений ним орган виплачує працівникові за виконану ним роботу. Розмір заробітної плати залежить від складності та умов виконуваної роботи, профеесійно-ділових якостей працівника, результатів його праці та господарської діяльності підприємства [8]. Однак таке визначення $є$ достатньо поверховим, що не дає змогу глибоко проаналізувати і зрозуміти як економічні, так і соціальні аспекти цього поняття. Зауважимо, що в економічній літературі відсутній єдиний підхід до трактування сутності заробітної плати.

Для осучаснення нормативної бази готується новий Трудовий кодекс - так попередньо називається новий звід правил, прав і обов'язків для працівників і роботодавців, що має прийти на зміну нині чинному Кодексу законів про працю. Чинний Кодекс законів про працю був прийнятий у 1971 році, ще за часів Радянського Союзу. Цей документ багаторазово перероблювали, змінювали та доповнювали. Діючий Закон про працю не задовольняє вимогам сучасності. Ані роботодавцям, ані працівникам він нині не підходить, адже умови життя і ведення бізнесу змінилися. До того ж усі сторони господарювання вважають прописаний закон занадто складним 3 точки зору найму та звільнення працівників, а новий кодекс зокрема покликаний полегшити ці процедури [10].

На міжнародному рівні системи оплати праці більш орієнтовані на мотивацію працівників, ніж традиційні системи оплати праці в Україні. Основною перевагою нетрадиційних систем оплати праці $\epsilon$ їх зрозумілість та простота, підвищення стимулюючої фрункції заробітної плати, чого не можна сказати про системи оплати праці, які використовують суб'єкти господарювання в Україні [6, с. 256].

На цьому етапі вважаємо, що організація бухгалтерського обліку оплати праці повинна забезпечити реалізацію функцій заробітної плати, саме у такому випадку вона буде ефективною. Недарма вчені й досі намагаються виділити основні функції заробітної плати для сучасного розвитку бізнесу. За результатами останніх досліджень, у визначенні функцій заробітної плати, вчені виділяють такі основні фрункції заробітної плати: відтворювальну - як джерела відтворення робочої сили і засобу залучення людей до праці; стимулюючу - встановлення залежності рівня заробітної плати від кількості, якості і результатів праці; регулюючу - як засіб розподілу і перерозподілу кадрів по регіонах країни, галузях економіки з урахуванням ринкової кон'юнктури; соціальну - забезпечення соціальної справедливості, однакової винагороди за однакову працю [2, с. 140].

Проте в сучасних умовах заробітна плата не може виконувати цих функцій, нині вона виконує інші фрункції, а саме: збереження зайнятості, запобігання безробіттю ціною заниження заробітної плати; забезпечення соціальних гарантій; збереження попереднього статусу, пов'язаного із попереднім робочим місцем; стримування інфляції (шляхом заборгованості із заробітної плати); перерозподіл зайнятих по галузях і сфрерах економіки; поширення нелегальної діяльності та вторинної зайнятості; посилення мобільності робочої сили [6, с. 256].

Наведені функції заробітної плати тісно взаємопов'язані між собою, і лише за їхньої сукупної наявності досягається ефективна організація заробітної плати. Механізм реалізації основних фуннцій заробітної плати включає визначення їх цільової спрямованості, принципів реалізації, напрямів реалізації, критеріїв реалізації. У сучасних економічних умовах в Україні, які зумовлені недосконалими розподільчими відносинами та нерозвиненими ринковими механізмами, більшість розглянутих вище функцій та принципів організації заробітної плати не виконуються [2, с. 141].

Особливої уваги потребує визначення такого поняття, як мінімальна заробітна плата. Мінімальна заробітна плата - це законодавчо встановлений розмір заробітної плати за просту, некваліфіковану працю, нижче якого не може проводитися оплата за виконану працівником місячну, годинну норму праці (обсяг робіт). До неї не входять доплати, надбавки, заохочувальні та компенсаційні виплати. Мінімальна заробітна плата $є$ соціальною гарантією, обов'язковою на всій території України для підприємств усіх фрорм власності, та встановлюється Законом України «Про державний бюджет» (табл. 1).

Розмір мінімальної заробітної плати за роками

Таблиця 1

\begin{tabular}{|c|c|c|c|c|c|c|}
\hline \multirow{3}{*}{ Період } & \multicolumn{6}{|c|}{ Розмір мінімальної заробітної плати, грн. } \\
\hline & \multirow{2}{*}{$\begin{array}{c}\text { місячна, } \\
\text { грн }\end{array}$} & \multicolumn{2}{|c|}{ збільшення } & \multirow{2}{*}{$\begin{array}{c}\text { погодинна, } \\
\text { грн }\end{array}$} & \multicolumn{2}{|c|}{ збільшення } \\
\hline & & грн & $\%$ & & грн & $\%$ \\
\hline 1 & 2 & 3 & 4 & 5 & 6 & 7 \\
\hline з 01.01.2015 р. по 31.08.2015 р. & 1218 & 0 & 0 & 7,29 & 0 & 0 \\
\hline з 01.09.2015 р. по 31.12.2015 р. & 1378 & 160 & 13,1 & 8,29 & 1,00 & 13,7 \\
\hline з 01.01.2016 р. по 30.04.2016 р. & 1378 & 0 & 0 & 8,29 & 0 & 0 \\
\hline з 01.05.2016 р. по 30.11.2016 р. & 1450 & 72 & 5,2 & 8,69 & 0,40 & 4,8 \\
\hline з 01.12.2016 р. по 31.12.2016 р. & 1600 & 150 & 10,3 & 9,59 & 0,90 & 10,4 \\
\hline з 01.01.2017 р. по 31.12.2017 р. & 3200 & 1600 & 100,0 & 19,34 & 9,75 & 101,7 \\
\hline
\end{tabular}


продовження табл. 1

\begin{tabular}{|l|c|c|c|c|c|c|}
\hline \multicolumn{1}{|c|}{1} & 2 & 3 & 4 & 5 & 6 & 7 \\
\hline з 01.01.2018 р. по 31.12.2018 р. & 3723 & 523 & 16,3 & 22,41 & 3,07 & 15,9 \\
\hline з 01.01.2019 р. по 31.12.2019 р. & 4173 & 450 & 12,1 & 25,13 & 2,72 & 12,1 \\
\hline з 01.01.2020 р. & 4723 & 550 & 13,2 & 28,31 & 3,18 & 12,7 \\
\hline
\end{tabular}

Джерело: сорормовано авторами на основі [4; 7]

Тож з 01.01.2020 року працедавець не має права нараховувати зарплату працівникові за виконану місячну норму праці меншу за 4723 грн. Так, мінімальна заробітна плата в Україні протягом 2015-2019 років збільшилася на 3505 грн. або в 3,9 раза, в той час як середня заробітна плата за цей же період збільшилась на 6297 грн. (з 4207 грн. за 2015 рік до 10504 грн. за 2019 рік) - в 2,5 раза. Ці дані наводить Міністерство фрінансів України у звітах про результати діяльності.

За даними Державної служби статистики України, у грудні 2019 року середня заробітна плата в Україні складала 12264 гривень на місяць, що на 1585 гривень (або 14,8\%) більше, ніж у листопаді. За 2019 рік середня зарплата в Україні виросла на 16\% і у грудні вона була у 2,9 раза більшою, ніж мінімальна зарплата [3]. Протягом останніх років в Україні спостерігається стабільна тенденція зростання реальних доходів населення. За даними Державної служби статистики розподіл кількості штатних працівників за розмірами нарахованої заробітної плати виглядає таким чином (табл. 2).

Розподіл кількості штатних працівників за розмірами нарахованої заробітної плати

Таблиця 2 за IV квартал 2019 року

\begin{tabular}{|l|c|c|}
\hline \multicolumn{1}{|c|}{ Розміри нарахованої заробітної плати } & $\begin{array}{c}\text { Питома вага працівників, } \\
\%\end{array}$ & $\begin{array}{c}\text { Кількість штатних працівників, } \\
\text { тис. осіб }\end{array}$ \\
\hline до 4173,00 грн & 5,4 & 380,6 \\
\hline від 4173,01 до 4500,00 грн & 10,4 & 733,0 \\
\hline від 4500.01 до 5000,00 грн & 8,2 & 678,0 \\
\hline від 5000,01 до 6000,00 грн & 8,8 & 520,3 \\
\hline від 6000,01 до 7000,00 грн & 7,7 & 542,7 \\
\hline від 7000,01 до 8000,00 грн & 7,2 & 747,1 \\
\hline від 8000,01 до 10000,00 грн & 10,6 & 676,6 \\
\hline від 10000,01 до 12000,00 грн & 9,6 & 761,2 \\
\hline від 12000,01 до 15000,00 грн & 10,8 & 696,6 \\
\hline від 15000,01 до 20000,00 грн & 9,5 & 831,7 \\
\hline понад 20000,00 грн & 11,8 & 7048,3 \\
\hline Разом: & 100 & \\
\hline
\end{tabular}

Джерело: сфрормовано авторами на основі [3]

Незважаючи на позитивні статистичні показники щодо зростання заробітної плати в Україні за останні роки, оплата праці не дозволяє працівникам нормально відтворювати себе на ті кошти, які їй платить держава або роботодавець. Тобто найгострішою соціальною проблемою залишається велика різниця між кількістю працівників, які отримують високу заробітну плату понад 20 тис. грн, і кількістю працівників, які отримують низьку до 5 тис. грн. Проте служба статистики не приводить дані за розмірами нарахованої заробітної плати понад 20000 грн, наприклад від 20000 грн до 30000 грн, та вище до самої максимальної суми.

Низька заробітна плата основної частини населення в Україні призвела до масової міграції робочої сили за кордон. Нині, за оцінками міжнародних організацій, майже 5,8 млн наших громадян перебувають на постійних та тимчасових заробітках за кордоном і кількість бажаючих виїхати щороку зростає [2, с. 141].

Сума грошових переказів від заробітчан в Україну за 2019 рік склала 12,878 млрд грн, що на 12,2\% більше, ніж роком раніше (11,478 млрд грн). У повідомленні Національного банку України також відзначається, що збільшення обсягу готівкової валюти поза банками у 2019 році склало 3,374 млрд грн, що на 39,4\% більше, ніж роком раніше [3].

Позитивним моментом вважається те, що такі грошові надходження стимулюють внутрішній попит, стабілізують курс національної валюти та дозволяють розвиватися торгівлі. Однак саме міграція є причиною глибокої кризи на ринку праці України, яка насамперед позначається на гострому дефіциті трудових ресурсів. Якраз цю проблему слід вирішувати передусім на державному.

Проте низькі зарплати більшості українців - не єдиний чинник, через який їдуть українці. Загалом низькі зарплати - це дзеркало викривленого ставлення до праці людини в українській 
економіці, яка є в основному сировинною та олігархізованою за своєю суттю. У нашій державі звикли до достатньої кількості трудових ресурсів, яким можна платити небагато. Проте із відкриттям для українців глобальних трудових ринків, вітчизняна економіка просто не може витримувати конкуренцію із іншими державами [10].

Зокрема, Польща, Чехія, Словаччина, Угорщина і навіть Німеччина конкурують за українських трудових мігрантів. Адже економіка цих країн відчуває гостру нестачу як кваліфікованої, так і некваліфікованої робочої сили. Уряд України за головну мету ставить підвищення мінімальної заробітної плати, що мала б стимулювати роботодавців підвищувати заробітки найманих працівників для суттєвого зменшення відтоку трудових мігрантів. Проте вже зараз зрозуміло, що досягти таких показників без суттєвих змін в економіці України буде практично неможливо [10].

Крім всього вище перерахованого, мінімальна заробітна плата є основою для визначення державних тарифрів у сфері оплати праці, пенсій, стипендій, допомоги та інших соціальних виплат. Розмір мінімальної заробітної плати визначається на основі прожиткового мінімуму, який розраховується за нормативами задоволення мінімальних потреб у товарах і послугах з урахуванням рівня цін. Динаміку росту розміру прожиткового мінімуму за 2019 рік та планові показники на 2020 рік подано у табл. 3.

Таблиця 3

\section{Розмір прожиткового мінімуму}

\begin{tabular}{|l|c|c|c|c|c|c|}
\hline \multirow{2}{*}{\multicolumn{2}{c|}{ Показники }} & \multicolumn{3}{|c|}{2019 р. } & \multicolumn{3}{c|}{2020 р. (планові показники) } \\
\cline { 2 - 8 } & $\begin{array}{c}\text { січень - } \\
\text { червень }\end{array}$ & $\begin{array}{c}\text { липень - } \\
\text { листопад }\end{array}$ & грудень & $\begin{array}{c}\text { січень - } \\
\text { червень }\end{array}$ & $\begin{array}{c}\text { липень - } \\
\text { листопад }\end{array}$ & грудень \\
\hline для працездатних осіб & 1762 & 1841 & 1921 & 2102 & 2197 & 2270 \\
\hline для непрацездатних осіб & 1373 & 1435 & 1497 & 1638 & 1712 & 1769 \\
\hline для дітей віком до 6 років & 1492 & 1559 & 1626 & 1779 & 1859 & 1921 \\
\hline для дітей віком від 6 до 18 років & 1860 & 1944 & 2027 & 2218 & 2318 & 2395 \\
\hline
\end{tabular}

Джерело: сформовано авторами на основі [7]

Прожитковий мінімум щорічно встановлюється Кабінетом Міністрів України та затверджується Верховною Радою України при прийнятті Державного бюджету України на рік. Він $€$ базовим державним стандартом, на підставі якого визначаються державні соціальні гарантії та стандарти у сорерах доходів населення, житлово-комунального, побутового та соціально-культурного забезпечення.

Згідно Податкового кодексу України, до складу видатків платника податків включаються видатки на оплату праці фрізичних осіб, що мають трудові відносини з таким платником податку, які включають нараховані витрати на оплату основної та додаткової заробітної плати та інші види заохочень та виплат, у вигляді премій, відшкодування вартості товарів, робіт, послуг, витрати на оплату авторського винагородження та за виконання робіт, послуг згідно із договором, а також будь-яка інша оплата у грошовій або натуральній формі згідно із колективним договором [5].

Податки та платежі, об'єктом оподаткування яких є заробітна плата, на нашу думку, можна поділити на дві категорії: одні - нараховуються на фонд оплати праці - сплачує підприємство за рахунок власних коштів, інші - утримуються із заробітної плати працівників, а підприємство виступає податковим агентом, перераховуючи їх до бюджету.

До першої категорії належить єдиний соціальний внесок. Усі суб'єкти господарювання в Україні, незалежно від форми власності, повинні здійснювати нарахування ЄСВ на фронд оплати праці працівників, які працюють на умовах трудового та цивільно-правового договорів. Роботодавці зобов'язані щомісяця подавати до фріскальних органів звітність 3 єдиного соціального внеску за найманих працівників [9].

Законом України «Про Державний бюджет України на 2020 рік» встановлено:

а) максимальна величина бази нарахування ЄСВ - дорівнює 15 розмірам прожиткового мінімуму для працездатних осіб. Розмір максимальної величини бази нарахування ЄСВ на 2020 рік складає 70845 грн. (4723 грн. × 15) [7];

б) мінімальний страховий внесок - сума ЄСВ, що визначається розрахунково як множення мінімального розміру заробітної плати на розмір внеску, встановлений на місяць, за який нараховується заробітна плата (дохід), та підлягає сплаті щомісяця [7]. Крім основної ставки 22\%, пільгові категорії платників можуть застосовувати зменшені розміри (табл. 4).

Платниками другої категорії податків є наймані працівники, із заробітної плати яких утримується податок на доходи фрізичних осіб (далі ПДФО) за ставкою 18\% і військовий збір в розмірі 1,5\%. ПДФО загальнодержавний податок, що стягується з доходів фрізичних осіб і нерезидентів, які отримують доходи з джерел їх походження в Україні. 


\section{Розрахунок мінімального страхового внеску в розрахунку}

\begin{tabular}{|l|c|c|}
\hline \multicolumn{1}{|c|}{ Категорії платників } & $\begin{array}{c}\text { Розмір } \\
\text { ставки ЄСВ }\end{array}$ & $\begin{array}{c}\text { Розрахунок мінімального страхового } \\
\text { внеску в розрахунку на місяць }\end{array}$ \\
\hline $\begin{array}{l}\text { 1. Підприємства (крім зазначених у пп. 3 і 4 цієї } \\
\text { таблиці), самозайняті особи на доходи звичайних } \\
\text { працівників }\end{array}$ & $22 \%$ & 4723,00 грн × 0,22 = 1039,06 грн \\
\hline $\begin{array}{l}\text { 2. Підприємства (крім зазначених у пп. 3 і 4 цієї } \\
\text { таблиці) і фізособи-підприємці на доходи } \\
\text { працівників-інвалідів }\end{array}$ & $8,41 \%$ & 4723,00 грн × 0,0841 = 397,20 грн \\
\hline $\begin{array}{l}\text { 3. Підприємства всеукраїнських громадських } \\
\text { організацій інвалідів, зокрема товариств УТОГ і } \\
\text { УТОС }\end{array}$ & $5,3 \%$ & 4723,00 грн × 0,053=250,32 грн \\
\hline $\begin{array}{l}\text { 4. Підприємства й організації громадських } \\
\text { організацій інвалідів }\end{array}$ & $5,5 \%$ & 4723,00 грн × 0,055=259,77 грн \\
\hline
\end{tabular}

Джерело: сформовано авторами на основі [5]

Основні положення, що визначають порядок оподаткування ПДФО, встановлені Податковим кодексом [5]. Відповідно до п. 169.1 Податкового кодексу, платник податків має право на зменшення суми загального місячного оподатковуваного доходу, отримуваного від одного роботодавця у вигляді заробітної плати, на суму податкової соціальної пільги (ПСП). Своєю чергою, ПСП застосовують до доходу (у вигляді зарплати), нарахованого на користь платника податку протягом звітного податкового місяця, якщо розмір такого доходу не перевищує суми, яка дорівнює розміру місячного прожиткового мінімуму, діючого для працездатної особи станом на 1 січня звітного податкового року, помноженого на 1,4 й округленого до найближчих 10 грн [5, пп. 169.4.1]. Якщо розмір прожиткового мінімуму для працездатної особи станом на 01.01.2020 року дорівнює 2102 грн, граничний дохід для застосування ПСП у 2020 році становить: 2102 грн × 1,4 = 2940 грн. Виходить, що ПСП не застосовуватимуть до доходів переважної більшості працівників, бо розмір їх зарплати має бути вищим за 4723 грн, а граничний дохід для застосування ПСП на 2020 рік - 2940 грн.

Отже, загальною ПСП зможуть скористатися лише працівники на умовах неповного робочого часу, та деякі пільгові категорії, зазначені у ПКУ п. 169 [5].

Ставка військового збору становить 1,5\% від об'єкта оподаткування. Об'єктом оподаткування військовим збором є: доходи у формі заробітної плати, інших заохочувальних та компенсаційних виплат або інших виплат і винагород, які нараховуються (виплачуються, надаються) платнику у зв'язку з трудовими відносинами та за цивільно-правовими договорами, тощо.

Інформаційне забезпечення операцій з оплати праці відображається у складі статистичної, фрінансової, податкової та спеціальної звітності. У зв'язку із зростанням кількості звітних документів, органів контролю та часу на підготовку кожного звіту питання автоматизованої підготовки та електронного подання в Україні використовується за єдиним уніфікованим стандартом програма створення і функціонування автоматизованої системи «Єдине вікно подання електронної звітності». Обов'язковість представлення податкової звітності контролюючим органам виключно в електронній формі передбачена лише для платників податків, що відносяться до крупних і середніх підприємств. Інші платники мають право подавати звітність в електронній формі за власним бажанням [5].

Для платників податків Державна фріскальна служба України пропонує безкоштовні програми для формування податкової звітності. За допомогою цих програм можна сформувати будь-який податковий звіт та зберегти його у потрібному фрорматі. Після цього на документ накладається електронний цифровий підпис, проводиться його шифрування та відправка до податкової служби засобами телекомунікаційного зв'язку, тобто електронною поштою [1, с. 368].

Висновки 3 проведеного дослідження. В умовах ринкової економіки заробітна плата $\epsilon$ важливою характеристикою ринку праці, визначається умовами цього ринку і одночасно їі рівень визначає попит на працю та її пропозицію. Заробітна плата поєднує інтереси та потреби працівників, роботодавців та держави, тобто визначає ефективність соціально-трудових відносин. Отже, за результатами проведеного дослідження встановлено:

1) у сучасних умовах розвитку України правильний і дієвий облік витрат на оплату праці на підприємстві повинен стати не лише засобом дотримання вимог чинного законодавства, а й джерелом надійної інфрормації для подальшого контролю та управління витратами на оплату праці;

2) нарахована заробітна плата працівникам на підприємстві має залежати безпосередньо від результатів праці й у той же час впливати на його показники, стимулювати розвиток виробництва, ефективність роботи, підвищення кількісних і якісних результатів праці;

3) реформування оплати праці на основі кардинальної зміни принципів ії̈ організації створить базу мотиваційного механізму підвищення трудової активності працівників.

Концептуальною проблемою України є обмеження сфери державного втручання у систему регулювання механізму оплати праці. Головними причинами загострення проблеми державного 
регулювання є: все ще слабкий дієвий контроль з боку держави за політикою оплати праці; недосконалість науково-методичного забезпечення процесу регулювання оплати праці; недосконале виконання чинного законодавства.

\section{Література}

1. Бражнікова Л. М., Гарна С. О., Шнурко А. М. Особливості формування системи електронної звітності на підприємствах України. Інфраструктура ринку. 2020. №39. C. 365-370. URL: https://www.market-infr.od.ua/uk/39-2020 (дата звернення: 02.01.2020).

2. Гончар Л. В., Гарна С. О., Шнурко А. М. Актуальні питання сучасного стану заробітної плати в Україні. Інноваційна економіка. 2019. № 5-6(80). С. 139-143.

3. Державна служба статистики України : Офріційний веб-сайт. URL: http://www.ukrstat.gov.ua (дата звернення: 02.01.2020).

4. Мінімальна зарплата в Україні. URL: http://dt.ua/ECONOMICS/ (дата звернення: 02.02.2020).

5. Податковий кодекс України : Закон України від 02.12.2010 № 2755-VI / Верховна Рада України. URL: https://zakon.rada.gov.ua/laws/show/2755-17 (дата звернення: 17.01.2020).

6. Поліщук П. В. Аналіз методів та систем оцінки і оплати праці. Вісник Хмельницького національного університету. Економічні науки. 2011. № 3. Т. 3. С. 255-258.

7. Про Державний бюджет України на 2020 рік : Закон України від 06.02.2020 № 294-IX. URL: https://zakon.rada.gov.ua/laws/show/294-IX (дата звернення: 07.02.2020).

8. Про оплату праці: Закон України від 24.03.1995 № 108/95-BP. URL: http://zakon4.rada.gov.ua/laws/show/108/95-вр (дата звернення: 26.12.2019).

9. Про збір та облік єдиного внеску на загальнообов'язкове державне соціальне страхування : Закон України № 2464-VI від 01.01.2013. URL: http://zakon2.rada.gov.ua/laws/show/2464-17 (дата звернення: 02.01.2020).

10.Радчук О. Повернення трудових мігрантів: що не так робить держава Слово і діло. 18 жовтня 2019. URL: https://www.slovoidilo.ua/2019/10/18/kolonka/aleksandr-radchuk/suspilstvo/povernennyatrudovyx-mihrantiv-ne-tak-robyt-derzhava (дата звернення: 02.01.2020).

\section{References}

1. Brazhnikova, L.M., Harna, S.O. and Shnurko, A.M. (2020), "Features of the formation of electronic reporting systems at Ukrainian enterprises", Infrastruktura rynku, no. 39, pp. 265-370, available at: https://www.market-infr.od.ua/uk/39-2020 (access date January 02, 2020).

2. Honchar, L.V., Harna, S.O. and Shnurko, A.M. (2019), "Actual issues of the current state of wages in Ukraine", Innovatsiina ekonomika, no. 5-6(80), pp. 139-143.

3. Derzhavna sluzhba statystyky Ukrainy: ofitsiinyi veb-sait [State Statistics Service of Ukraine: The official website], available at: http://www.ukrstat.gov.ua (access date January 02, 2020). 2020).

4. "Minimum wage in Ukraine", available at: http://dt.ua/ECONOMICS/ (access date January 02 ,

5. Verkhovna Rada Ukrainy (2010), Podatkovyi kodeks Ukrainy [Tax Code of Ukraine], Zakon Ukrainy dated 02.12.2010 no. 2755-VI, available at: https://zakon.rada.gov.ua/laws/show/2755-17 (access date January 17, 2020).

6. Polishchuk, P.V. (2011), "Analysis methods and evaluation systems and pay", Visnyk Khmelnytskoho natsionalnoho universytetu. Ekonomichni nauky, no. 3, Vol. 3, pp. 255-258.

7. Verkhovna Rada Ukrainy (2020), Pro Derzhavnyi biudzhet Ukrainy na 2020 rik [About the State Budget of Ukraine for 2020], Zakon Ukrainy dated 06.02.2020 no. 294-IX, available at: https://zakon.rada.gov.ua/laws/show/294-IX (access date February 07, 2020).

8. Verkhovna Rada Ukrainy (1995), Pro oplatu pratsi [About Payment of Labour], Zakon Ukrainy dated 24.03.1995 no. 108/95-VR, available at: http://zakon4.rada.gov.ua/laws/show/108/95-vr (access date December 26, 2019).

9. Verkhovna Rada Ukrainy (2013), Pro zbir ta oblik yedynoho vnesku na zahalnooboviazkove derzhavne sotsialne strakhuvannia [On the collection and accounting of the single contribution to compulsory state social insurance], Zakon Ukrainy dated 01.01 .2013 no. 2464-VI, available at: http://zakon2.rada.gov.ua/laws/show/2464-17 (access date January 02, 2020).

10.Radchuk, O. (2019), "Return of migrant workers: what the state does in word and deed", Slovo $i$ dilo, 18 October, available at: https://www.slovoidilo.ua/2019/10/18/kolonka/aleksandrradchuk/suspilstvo/povernennya-trudovyx-mihrantiv-ne-tak-robyt-state (access date January 02, 2020).

Стаття надійшла до редакції 12.02.2020 p. 